\title{
Nursing in the logbooks of sessions of the Houses of the Portuguese monarchy, between 1900 and 1910
}

Enfermagem nos diários das sessóes das câmaras do reino de Portugal, entre 1900 e 1910 Enfermería en los diarios de las sesiones de las cámaras del Reino de Portugal entre 1900 y 1910

Paulo Joaquim Pina Queirós*iD; António José de Almeida Filho**iD; Aliete Cunha-Oliveira***iD;

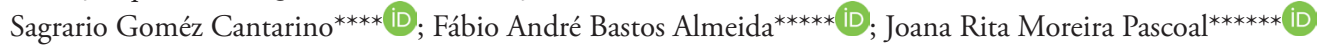

\begin{abstract}
Background: The first 10 years of the 20th century in Portugal corresponded to the last decade of the monarchy. A period of political and social turmoil, across a great continental and overseas space, where after the creation of the first nursing schools, in the 1880 s, signs of the slow process of professionalization of nursing are expectedly found.

Objective: To analyze the references to nurses and nursing in the House of Lords and House of Commons, from 1900 to 1910 .

Methodology: Historical research in the logbooks of sessions, with the survey, analysis, and interpretation of sources.

Results: Four thematic blocks were identified: naval nursing, military nursing, colonial health services, and naval nurses practice school; religion in healthcare; control of epidemics; the fund for the alienated, alienated criminals, the incisive speech by José de Almeida.

Conclusion: Professionalized nursing was more advanced in the military sector than in the civil sector. Healthcare delivery to the alienated, control of epidemics, and religious inspire references to nurses in both Houses.
\end{abstract}

Keywords: Portugal; nurses; history of nursing

\section{Resumo}

Enquadramento: Os primeiros 10 anos do século XX, em Portugal, corresponderam à última da década da monarquia. Um período política e socialmente conturbado, num grande espaço continental e ultramarino, em que após a criação das primeiras escolas de enfermagem, na década de 80 do século XIX, é expetável encontrarem-se sinais do lento processo de profissionalização da enfermagem.

Objetivo: Analisar as referências a enfermeiros e enfermagem na Câmara dos Pares e dos Senhores Deputados, de 1900 a 1910 .

Metodologia: Pesquisa histórica nos diários das sessóes, com levantamento, análise e interpretação de fontes.

Resultados: Identificados quatro blocos temáticos: A enfermagem na marinha, no exército, serviços de saúde colonial e a escola prática de enfermeiros navais; A questão religiosa na assistência; controlo de epidemias; o fundo dos alienados, alienados criminosos, o incisivo discurso de José de Almeida.

Conclusáo: Profissionalização da enfermagem mais avançada no setor militar que no civil. A assistência a alienados, o controlo das epidemias e a questáo religiosa motivam referências a enfermeiros em ambas as câmaras.

Palavras-chave: Portugal; enfermeiras e enfermeiros; história da enfermagem

*Ph.D., Coordinating Professor, Nursing School of Coimbra. 3046-851, Coimbra, Portugal. Researcher, Health Sciences Research Unit (UICISA: E) [pauloqueiros@esenf.pt]. (1) https:// orcid.org/0000-0003-1817-612X. Contribution to the article: research design, literature review, orcid.org/0000-0003-1817-612X. Contribution to the article: research design, literature review,
methodology, data collection and analysis, conclusions, and final writing of the article. Address

methodology, data collection and analysis, conclusions, and final writing of the article. Address
for correspondence: Avenida Dias da Silva, n⿳0 115, 3000-137, Coimbra, Portugal.
***Ph.D., Professor, Anna Nery Nursing School, 20211-130, Rio de Janeiro, Brazil lajafilhos@ -Pm.i., Professor, Anna Nery Nursing School, 20211-130, Rio de Janeiro, Brazil ajafilhos@ gesign, condusion discussion, and final revision of the article.

design, conclusion discussion, and final revision of the article.
*** Ph.D. Invited Adjunct Professor, Nursing School of Coimbra, 3046-851, Coimbra Portugal. * : Pes.D., Invited Adjunct Professor, Nursing School of Coimbra, 3046-851, Coimbra, Portugal Researcher, Health Sciences Research Unit (UICISA: E). alietecunha@esenfc.pt]. (O https:/ orcid.org/0000-0001-8399-8619. Contribution to the article: research design, iterature
methodology, data collection and analysis, conclusions, and final writing of the article. methodology, data collection and analysis, conclusions, and final writing of the article. fermería y Fisioterapia de Toledo 45071, Toledo, Spain [Sagrario.Gomez@uclm.es]. (D termeria y Fisioterapia de Toledo, 4507, Toledo, Spain Sagrario.Gomez@uclm.es]. (D) https://orcid.org/0000-0002-9640-0409. Conth
discussion, and final revision of the article.

discussion, and final revision of the article. *. Nursing Undergraduate Student, Nursing School of Coimbra, 3046-851, Coimbra, Portution to the article: literature review, data collection and analysis.

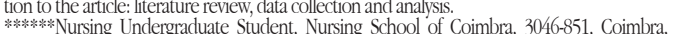

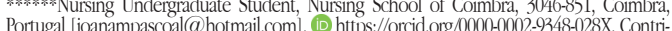
bution to the article: literature review, data collection and analysis, conclusions, abstracts, and final revision of the article.

\section{Resumen}

Marco contextual: Los primeros 10 ańos del siglo XX en Portugal correspondieron a la última década de la monarquía. Se trata de un período política y socialmente problemático, en un gran espacio continental y de ultramar, en el que, tras la creación de las primeras escuelas de enfermería en los años 80, cabe esperar signos del lento proceso de profesionalización de la enfermería.

Objetivo: Analizar las referencias a los enfermeros y a la enfermería en la Cámara de los Diputados, de 1900 a 1910.

Metodología: Investigación histórica en los diarios de las sesiones, con recopilación de información, análisis e interpretación de las fuentes.

Resultados: Se identificaron cuatro bloques temáticos: La enfermería en la marina, el ejército, los servicios coloniales de salud y la escuela práctica de enfermería naval; el tema religioso en la asistencia; el control de epidemias; el trasfondo de los enajenados y criminales enajenados, el discurso incisivo de José de Almeida.

Conclusión: Profesionalización de la enfermería más avanzada en el sector militar que en el civil. La asistencia a los enajenados, el control de las epidemias y el tema religioso son el motivo de las referencias a los enfermeros en ambas cámaras.

Palabras clave: Portugal; enfermeras y enfermeros; historia de la enfermería 


\section{Introduction}

This research is part of a broader study project on nursing and nurses in the successive Portuguese houses of representatives between 1820-1910, during the Portuguese Constitutional Monarchy. In Portugal, the last years of the Constitutional Monarchy (1900-1910) were a transition period. The British Ultimatum of 1890 and the consequent republican revolt in Porto on 31 January 1891 mark the path which led the first Portuguese liberalism to an end (Rosas \& Rollo, 2009). These authors affirm that "The crisis was global. In addition to the immediate political crisis, the widespread social malaise, the economic crisis, and the clashing financial collapse made up the catastrophic scenario" (Rosas \& Rollo, 2009, p. 27). According to Sardica (2001), "the turn of the $19^{\text {th }}$ century to the $20^{\text {th }}$ century gave rise to confusing and difficult times in all quadrants of Portuguese life while propagating an omnipresent sensation of "crisis' and 'decay" (p. 488). This historian adds that "the party-political instability annihilated rotativismo, downgraded the monarchical parliament, and subjected, firstly, D. Carlos and, then, D. Manuel II to a deterioration that was eventually fatal" (Sardica, 2001, p. 491). As stated by Rosas (2010, p. 47), "the monarchy's global stalemate after the ultimatum crisis in 1890 triggered a live and prolonged debate in Portuguese society about the workarounds to the fatal walk toward the abyss". From the strict political perspective, it should be noted that " $D$. Carlos and the Royal Prince were murdered on the evening of 1 February 1908. The incident caused consternation, but was not enough to rekindle monarchist sentiments of loyalty," states Bonifácio (2010, p. 172), adding that "the regime fell easily apart, as we all know because nobody was willing to defend it" (Bonifácio, 2010, p. 174).

In this period, two Portuguese houses of representatives operated in a bicameral system: the House of Lords (CPR - Câmara dos Pares do Reino); and the House of Commons (CSDNP - Câmara dos Senhores Deputados da Nação Portuguesa). The CPR began operating on 10 July 1842 and came to a close on 25 June 1910. Composed of peers whose membership was hereditary (royal prince, infantes, and clerical peerage) or by-election, it was based on a mixed system of royal appointment of $2 / 3$ of the members and $1 / 3$ of elected members. In addition to its legislative function, the CPR assembled in the Court of Justice. The CSDNP run from 15 November 1822 to 25 June 1910, and its competencies were proposed legislation, through bills. The proposals of the Government could be converted into bills after being examined by a committee (Assembleia da República, 2019a; Assembleia da República, 2019b).

In the turn of the $19^{\text {th }}$ to the $20^{\text {th }}$ century, the nursing profession went through the first moments of professionalization, in a movement of tenuous and gradual affirmation in society. During these years, school training of nurses began in Portugal. According to Silva (2008), the nursing school of the Coimbra University Hospitals (1881), the nursing school of the Royal Hospital of S. José, in Lisbon (1887), the nursing course of the Hospital da Marinha, in Lisbon (1888), the nursing school of the General Hospital of S. António da Misericórdia in Porto (1897), the nursing school of the Military Hospital of Porto (1909); the nursing school of the Hospital of S. Marcos da Misericórdia in Braga (1912) were created. Regarding military nursing, army, and navy, Ferreira (2012) mentions the presence, in 1842, of nurses in the regulation of the military health services, their decreased autonomy in the new regulation of 1853 , and their still evident presence in the army's general health regulation of 1909 . As to the navy, the presence of nurses is noted in the regulations of $1860,1871,1886,1896$, and 1908 . On the other hand, civil and religious nursing, during 1900-1910, underwent an overt process of professional organization in hospital settings, either dependent of the Misericórdias, or in civil hospitals of Lisbon and Coimbra (Santos, 2012). A movement of professionalization reflected on the increasing school training and the proliferation of hospital regulations.

The objective knowledge of the history of nursing, free from ideological constructions and professional myths, will contribute to the perception of the processes of construction of the professional identity, of the steps of the professionalization of nursing in Portugal, and the development of its expertise as a nursing science. The societal constraints currently affecting the nursing profession will be more clarified with the reading of its historical evolution, demonstrating 
that the long journey of the professionalization of nursing in Portugal started in the late $19^{\text {th }}$ century (formal existence of the first schools) and ended in the late $20^{\text {th }}$ century (constitution of the autonomous regulatory body - Ordem dos Enfermeiros). Also, in parallel, but differentiated in time, the process of autonomization and disciplinary affirmation - autonomous knowledge, with the status of nursing science, began in the late $20^{\text {th }}$ century and is under development today. This study was developed within the scope of the structuring project: History and epistemology of health and nursing, of the Health Sciences Research Unit: Nursing (UICISA: E). It aims to respond to what, in Portugal, during that period, was discussed in its various Houses between the representatives of the country about nurses and nursing.

This project, due to its broad time scope, was mandatorily developed in chronological segments of lower amplitude, giving rise to parceled summaries which, gradually, will merge into a joint vision. This article, as a parceled research report, deals with the study in the period of 1900 to 1910 . Its goals are to analyze the references to nurses and nursing in the House of Lords and the House of Commons from 1900 to 1910.

\section{Methodology}

This research used a historical methodology, based on documentary analysis: the daily sessions of the Houses at the end of the monarchy.

First, it identified the empirical material, relevant sources which were analyzed, systematized and interpreted.

The sources are used by the historian to perform his/her work (Mendes, 1989), considering that the sources of varied nature still cannot be considered history, but only working material to be used by the historian within his/her professional scope (Mendes, 1989). Based on the sources, the historian examines the past using its brands and elaborates the historic speech, constructing the resulting mental representation and, finally, the production of a written or oral text that allows communicating his/her conclusions (Mattoso,1997).

The objectively built historic speech takes into account that the "scientificity of history's modern science does not lie on it narration, but instead on its description, analysis, and explanation" (Rüsen, 2001, p. 119), regarding history as a "complex, broad, and defined, explaining and problematizing knowledge" (Torgal, 2015, p. 50). In this sense, it has its methods of analysis and specific theorization, not being limited to the "positivist" vision of just letting the sources talk. This study is the result of the survey and analysis of documental sources, specifically of the CPR and CSDNP, accessible on the website of the Assembly of the Republic. Through the available search engine, the logbooks' pages were found, using the following descriptors: female nurse (s); male nurse(s); ward(s); nursing. Then, the documental sources were selected and classified after assessing the quality and relevance of their content (Filho et al., 2015). Thus, the topics were analyzed, contextualized and explained according to the proposed objectives, such as: the survey of topics related to nursing and nurses; analysis of material and thematic and joint interpretation for the study's 11-year period; perception of topics and matters in which the legislative elites were interested; formulation of a analytical and interpretative text, illustrated with quotes from sources. This study, while identifying the contents of the discussions about nurses and nursing, as well as the study of the absences in a certain historical period, creates opportunities to perceive the positioning of nursing in Portuguese society at that time (Queirós, Filho, Monteiro, Santos, \& Peres, 2017). Consequently, particularly relating to the references in the logbooks of the sessions, it can contribute to the construction of the nursing historical narrative at the end of the constitutional monarchy.

\section{Results and Discussion}

The research allowed identifying, in the logbooks of the sessions of the two Houses, during these 11 years of the end of the monarchy, a total of 245 entries (words collected by each descriptor), with a distribution of 53 entries for the CPR and 192 for CSDNP. The dispersion of the number of entries throughout the period allows noting a higher quantitative expression in 1902 and 1903 (47 and 38 entries, respectively), followed by 1909 with 34 and 1907 with 25. A smaller expression occurs in 1905 and 1906 with 
two and three entries. In 1905, the Houses operated in a more reduced period, as there was only a total of 58 daily sessions for both Houses, in contrast with the other years of the period, with values between 69 logbooks for 1910 and 198 for 1903. The analysis of each
House observes that there are no entries in the CPR for 1905 and 1907, and no entries for CSDNP in 1906. In general, the number of entries is greater in the CSDNP. However, 1904 and 1906 present higher values in the CPR comparing to CSDNP (Figure 1).

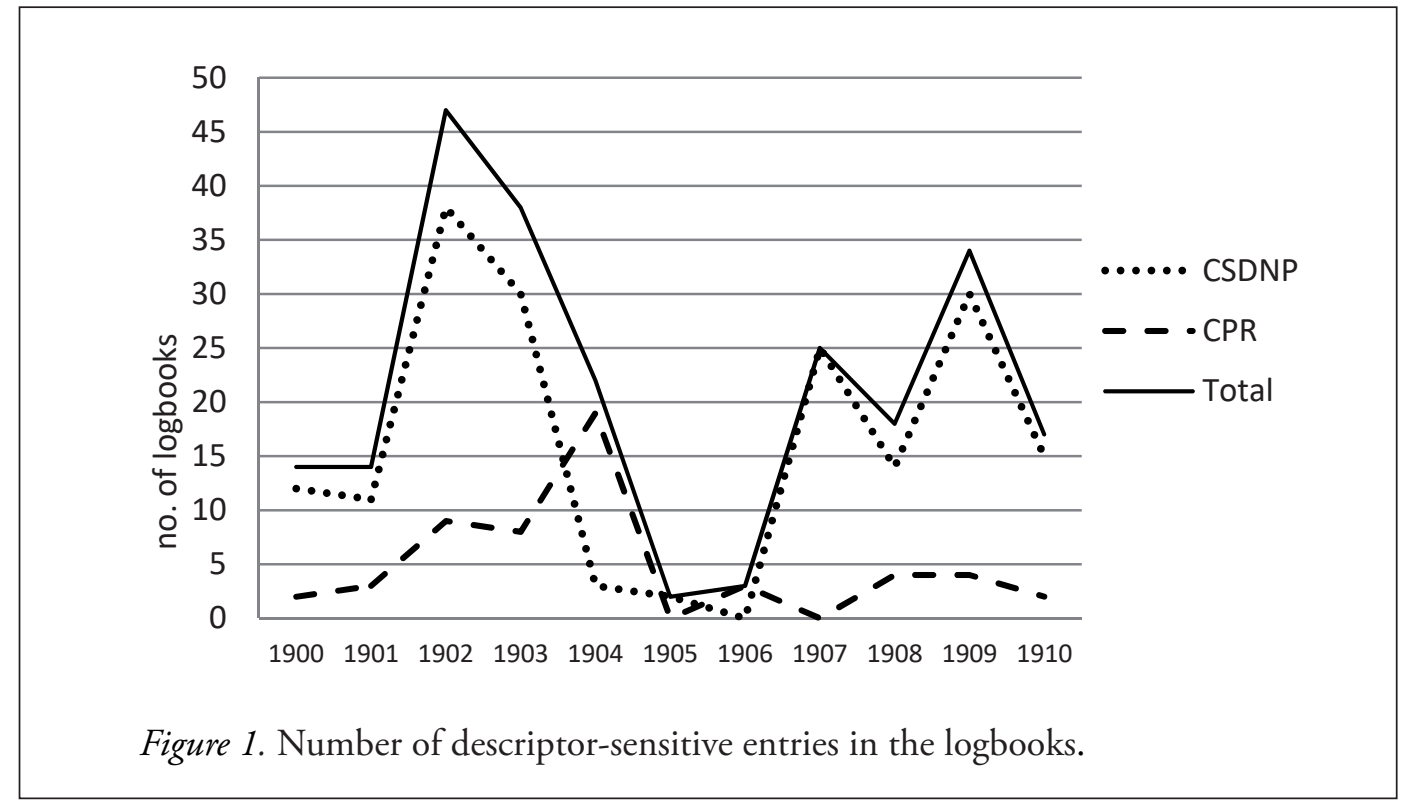

Crosschecking the number of descriptor-sensitive entries with the number of logbooks published per year for this period, with joint data sets for the two Houses, the correlation of the tendency of linear curves is evident, except in
1902, with a peak of entries and a decrease of the number of logbooks, leading to the possibility that this year is particularly significant for this study's descriptors (Figure 2).

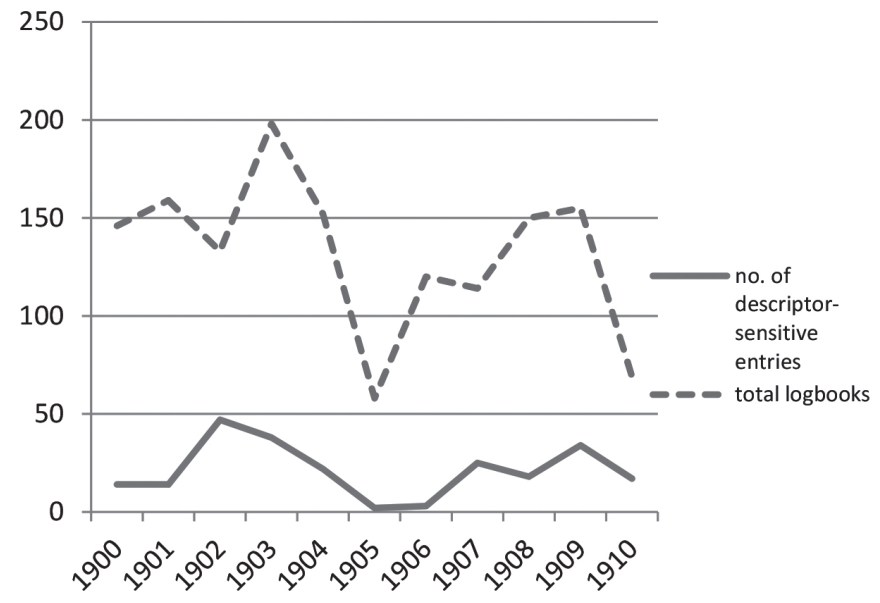

Figure 2. Number of descriptor-sensitive entries in the logbooks and total logbooks per year. 
The descriptors male nurse and male nurses add to the value of 96 entries, which contrasts with the descriptors female nurse(s), amounting to only 16 entries. It is important to consider the number of entries for the descriptor nursing, just 13 . These data are in line with other studies on the analysis of nurse references in the Houses of the Constitutional Monarchy because the personalized descriptors correspond to a very expressive numerical value when compared to the values of the descriptors that could reflect the professionalization, in this case, the descriptor nursing, which takes up only 13 entries in this 11 -year period. In this respect, the findings for 1821 and 1822 should be compared, in which the nursing de- scriptor found nothing (Queirós et al., 2018). The difference between the male and female descriptors will be consistent with the consideration of the male designation covering both genders, and not so much because of the translation of a greater number of present male nurses. However, many references are related to the nurses of the army and navy, and also, in this period, in civil hospitals, the number of male nurses was significant, contrary to the trend of female supremacy in the decades until today. It should also be noted that the number of entries per descriptor related to the ward(s) is numerically higher, in a total of 120 , which explains the presence of institutional aspects related to the spaces and their organization (Table 1).

Table 1

Number of entries per descriptor

\begin{tabular}{lc}
\hline Descriptors & Number of entries \\
\hline Male nurse & 55 \\
Male nurses & 41 \\
Female nurse & 13 \\
Female nurses & 3 \\
Nursing & 13 \\
Ward & 46 \\
Wards & 74 \\
\hline
\end{tabular}

The reading of the logbooks of the sessions, following the descriptors, has identified four thematic blocks: the first includes references to nursing in the navy, army, colonial health services, and naval nurse practice school; the second is related to the matter of religion and its effects on health/disease care; the third thematic block is related to the control of epidemics and hospital conditions; and finally, the fourth block is related to the fund for the alienated, the alienated criminals, and an incisive speech by José de Almeida.

\section{Military nursing}

In 1902, the theme of Colonial Hospital arises in Lisbon, "for the treatment of military officers and soldiers of enlisted ranks who return from overseas" (CPR, diário no 31, de 3 de abril de 1902; Assembleia da República, 2019a; p. 295), as well as the civil and clerical personnel also returning from overseas. In this hospital, "the teaching of special medicine of tropical climates" (CPR, diário no 31, de 3 de abril de 1902; Assembleia da República, 2019a, p. 295) will be carried out, the nursing staff will be seconded from overseas health companies and "will be designated in regulation, according to the service's requirements " (CSDNP, diário nº 24, de 26 de fevereiro de 1902, Assembleia da República, 2019b, p. 14). The "apprenticeship of nursing practitioners " (CPR, diário no 31 , de 3 de abril de 1902; Assembleia da República, 2019a, p. 295), provided for in previous legislation, must be carried out in this hospital from this day onward, "the lectures ... being performed by a volunteer on duty, who will understand the corresponding gratification." (CSDNP, diário no 24, de 26 de fevereiro de 1902, Assembleia da República, 2019b, p. 14). The Portuguese naval force includes in 1907-8 a pontoon hospital and, in 1909-10, a storage/ hospital ship, with 60 soldiers. The members 
of the army, in health services, in 1902, are described as the indispensable minimum: in the Directorate-General of Health Services, 57 members of which 46 are soldiers; and in the active army, 6 mobile hospitals with 108 members of which 78 are soldiers, 17 soldiers in the cavalry regiment, and 20 soldiers as nurses and drivers in the hunters' battalion.

In 1900, the CSDNP was concerned with the assessment of the requirements of pensioners of the Armada, with first and second nurses, including the requirement of grating, in addition to the enlisted rank, barracks, bread, and allowance for food. In this year, the bases for the organization of the naval artillery practice school were established. In 1902, an "Overseas Military Organization" is presented to manage the health services, stating that "in all locations where there are no hospitals, regimental wards should be organized" (CSDNP, diário no 6, de 17 de janeiro de 1902; Assembleia da República, 2019b, p. 77). In 1903, the mandatory residence of the nurse in the Naval School was mentioned. In the same year, a corporal of the health company demands equal salary for nurses with the rank of staff sergeants of the Armada, leading to the argument that the salaries of nurses should be equal to the foremen's and third brigade gaffers of the navy. In 1905, a ward in Gambos, Angola, was under construction. In 1906, there are old ships overseas serving as floating wards. And, in 1910, there was dissemination of information about the Naval Nurse Practice School, its regulations, conditions of admission, and functioning, stating that: "The nursing corporals who present good behavior, good information, and a one-year minimum of hospital service and one year onboard can attend the course of nurse sergeants at the Hospital da Marinha" (CSDNP, diário n 28, de 8 de junho de 1910; Assembleia da República, 2019b, p. 57). It was a course whose first year covers notions of anatomy and physiology, dressings and bandages, surgical instruments, emergency aid, transport of injured patients, asepsis, antisepsis, and frequent-use disinfectant and disinfection. The second year covers the medication, doses, routes of administration, toxic substances, poisoning, symptoms and antidotes, symptomatology of the most frequent diseases, balneotherapy, thermotherapy, massages, phar- maceutical analysis, and manipulation. "This course will include hospital practice in surgery, medicine, and special wards" (CSDNP, diário $\mathrm{n}^{\circ} 28$, de 8 de junho de 1910; Assembleia da República, 2019b, p. 57). In the same year, the navy brigade has soldiers with completed nurse training, for a total of two assistant sergeants, 20 master sergeants, 30 staff sergeants, and 12 corporals. The burden of the work of naval nurses is mentioned in 1910.

\section{Religion in healthcare delivery}

In 1904, the irmãs hospitaleiras (hospital sisters), the chaplain, doctors, and nurses ran the Hospital Maria Pia, in Luanda. The controversy was settled due to Father José Reyman being accused of imposing confession to the patients and the alleged extortion of money in benefit of a religious mission in Zimbabwe. He was also accused of providing pills without medical supervision. The controversy includes the bishop of Luanda, D. António since he accepted to visit a patient named Manuel Pereira and encountered a watchman at the door of the room, who did not let him in. Furthermore, it should be noted that the watchman was placed there because the patient complained about the intrusion of father Reyman, who bothered him with his warnings of confession. The actions of the chaplain were subjected to an investigation. Colonel Manuel Purificação Ferreira was appointed as investigator but could not prove any of the three accusation criteria (imposition of confession, extortion of money, and supply of drugs) because the necessary witnesses to the cabal clarification were absent. The nurse who could serve as a witness was, however, transferred to a less accessible location. It is also found that, by the pressure of the Father, the irmãs hospitaleiras adopt a persuasive attitude toward the patients, and that the priests of the Espírito Santo congregation are free of civilian and diocesan control, which constitutes a problem, also alluding to the alleged guilt in supporting the rebels of the Bailundo.

The second theme results from the application of the Peer of the Realm, Sebastiano Sirius, submitted to the Ministry of the Realm, requesting a copy of any concession granted to the lay-brothers of the Congregation of S. Filipe de Nery for entering the Hospital of S. José because they executed their influence on the 
patients admitted there, disturbing their freedom of conscience. Four years later, in 1910, the same Peer of the Realm noted that he received no reply to the application and found a publication from Lisbon in 1909, entitled "Congregants of S. Filipe de Nery based in the Hospital of S. José". It informed that a meeting of the above mentioned congregants was held at the hospital. Outraged, he demanded to the ministry the authorization of the action of these congregants, the nominal relationship with age, birthplace, and nationality of the congregants, whether they provide free or paid care, and the person responsible for this abuse committed against the current legislation. All these events must be regarded and understood in the light of this religious matter, with a recent background at the time of the signing of the agreement and the coming to Portugal of the French sisters in 1857. "Until 1910, several high points of Republican propaganda and mobilization occurred directly or indirectly related to the bustle of explicitly or implicitly anticlerical topics" (Bonifácio, 2010, p.165-166).

In 1908, the assemblyman Miguel Bombarda proposed a tribute to Joaquim António de Aguiar, highlighting his role in the expulsion of religious orders and emphasizing the need to remind people of the importance of freedom. He stated that "the history of religious orders is a dreadful history of blood, torture, and martyrdom" (CSDNP, diário $n^{\circ} 78$, de 25 de agosto de 1908; Assembleia da República, 2019 b, p. 10), as "the congregation [is] the cancer of societies" and the "friar [is] even worse than cancer" (CSDNP, diário no 78 , de 25 de agosto de 1908; Assembleia da República, 2019b, p. 10). Finally, he declared, "indeed, the congregant charity is not only a signboard but also a falsehood. Religious nursing is false nursing, which entails dangers to patients." (CSDNP, diário no 78, de 25 de agosto de 1908; Assembleia da República, 2019b, p. 10). The matter of religious nursing and secular nursing in public hospitals is present in these years.

\section{Control of epidemics}

On 25 January 1900, in the CPR, according to the logbooks of sessions, the Earl of Casal Ribeiro commented on the state of health of Coimbra, referring a smallpox epidemic that had begun to manifest itself in August 1899, affecting almost exclusively common people living in precarious hygienic conditions.

As soon as the epidemic arose, the authorities adopted the necessary measures, establishing two free vaccination stations, one uptown, and another downtown. They ordered the police to monitor the manifestation of any case, demanded men to vaccinate and revaccinate their families, organized these services in four geographic areas, each of which was run by the respective municipal doctor, who was assigned to visit the homes because, "as it generally happens, the people are reluctant to vaccinate and even to receive medical care". Finally, "it was decided that the homes with smallpox must be isolated and rigorously disinfected, with formalin, using Trillate machines, provided by the City Council" (CPR, diário n 5, de 25 de janeiro de 1900; Assembleia da República, 2019a, p. 33).

Later, the entry states that Coimbra had the first scientific establishment in the country and, therefore, at the time of the year (January) students from various areas of the country join the city's already numerous population, whose debt is great to "their families because of their health and well-being, as well as their studies" (CPR, diário $\mathrm{n}^{\mathrm{0}}$ 7, de 3 de fevereiro de 1900; Assembleia da República, 2019a, p. 44).

These same students, when returning on holiday to their hometown, could spread the epidemic, however benign, because the city was in need of special hygiene attention, as "Coimbra has been almost abandoned in matters of sanitation, and the government must ensure hygienic measures" (CPR, diário no 7 , de 3 de fevereiro de 1900; Assembleia da República, 2019a, p. 44).

Taking into account the bubonic plague outbreak in Porto, the minutes of 8 March 1900 of the House of Commons mentions the report by Ricardo Jorge of 28 July 1899 on the bubonic plague outbreak in Porto and the communication by the civil governor of Aveiro, on 19 July, of some cases of the disease in the village of Argoncilhe, in the municipality of Feira, and of two cases of bubonic plague in children of a male nurse who worked in Porto with some patients with bubonic plague. The minutes also state that, in the face of the report, the government did nothing. Until 5 August, regarding hygiene and prophylaxis of plague in 
Porto, the government only had ordered the preparations of the hospital of Goelas de Pau, two months after the outbreak in that city. On 6 August 1899, Ricardo Jorge, in a letter to the government, claimed the diagnosis of plague was completed, recommending the delivery of a newsletter to all doctors to inform them that the plague dominated the city. The government replied to the letter on 8 August, ordering not the isolation of patients, but "that doctors were not to be noticed" (CSDNP, diário no 30 , de 8 de março de 1900; Assembleia da República, 2019b, p. 11).

On 7 March 1900, according to the logbook of sessions, the House of Commons discussed the decree-law that canceled, until further notice, all leisure trains, fairs, festivals, and other gatherings which, due to proximity or social relations, are used as a pretext for people to enter or leave Porto; that ordered, at the exit of Porto trains which had not been suppressed, the medical inspection of passengers and employees of those trains, and that did not allow anyone with manifested symptoms to continue traveling, even if only suspected of bubonic plague, and that all individuals from Porto were to be inspected on arrival at the destination and forced to present themselves to medical inspection for nine consecutive days. The inspection service at the arrival to the stations of the district capitals was organized in the same stations or some part of them. Any subsequent inspections, to which those coming from Porto were obligated to present themselves to, would be carried out in the locations indicated by the regional governors, in district capitals, and by the municipal administrators, in other locations. All individuals coming from Porto by train were given a note, which they must present at the inspection on arrival at their destination and in subsequent inspections, and a duplicate of that note was sent to the competent civil government or municipal administration. As soon as the trains from Porto reached the stations where sanitary inspection services were placed, the passengers from this city were transported to the inspection location and examined, the result being transcribed to these notes. If any passenger presented any suspicious symptom, he/she would be immediately sent, with the proper precautions and safety, to the hospital or isolation and observation stations for suspected individuals. Even if no inspection was performed on arrival of trains, the passengers were still obligated to present themselves, without further notice, within 12 hours and for nine consecutive days at the city council or similar administration office for medical examination. Until the special hospitals were ready, infected or suspected individuals were taken to the Lazareto de Lisboa and, in other regions, to private wards or temporary locations, under the appropriate conditions for this purpose (CSDNP, diário no 29, de 7 de março de 1900; Assembleia da República, 2019b, p. 13).

\section{The mental patients' fund and the incisive speech of António José de Almeida}

Bill no. 4 of 1903 on amendments to the prison system is described by António Cabral as "useless, contradictory, and defective" (CSDNP, diário no 17 , de 4 de fevereiro de 1903; Assembleia da República, 2019b, p. 6-7). He stresses that the construction of a ward for the alienated criminals would be much more useful. It was believed that madness evolved and expressed itself, in large part, because individuals are subjected to a prison system. However, cellular prison was not the sole determinant of madness, but also the morbid predisposition of prisoners. The annex hospital to the penitentiary was not yet open due to a trifle thing, such as the lack of lightning rod, lighting, and electrical buzzers, claiming that the lack thereof in a penitentiary as Lisbon's was deplorable. The Act of 1889, by António Senna, envisaged the construction of 4 hospitals (Lisbon, Coimbra, Porto, and Ponta Delgada), two wards adjacent to the Lisbon hospital and wards adjacent to central hospitals where the alienated criminals were admitted to. To meet the expenses, the fund of public beneficence for the alienated was created. The hospitals had precarious conditions to receive and treat mental health patients. When it came to welcome them, they were dead, or their state of disease was so advanced that treatment becomes useless.

The incisive speech by António José de Almeida highlights humanitarianism and social defense. "It is disgraceful to let the mad roam through the streets, ..., it is unhuman to let them suffer in the prisons, beaten and shackled. However, it is also dangerous to abandon them" (CSDNP, 
diário no 74, de 21 de agosto de 1908; Assembleia da República, 2019b, p. 25-26). Moreover, it accuses the government of allowing the procreation of the alienated and declares that the theoretical design is a sterile feeling because, in practice, "we are sloppy and cruel" (CSDNP, diário no 74, de 21 de agosto de 1908, p.25-26). Also, it accuses the government of spending the beneficence fund for the alienated, hindering the creation of these hospitals. "A repugnant crime has been committed in public beneficence in Portugal, and its stain will forever taint its wicked causers" (CSDNP, diário no 74, de 21 de agosto de 1908; Assembleia da República, 2019b, p. 25-26). José de Almeida believed that the specialized training of nurses allowed "attacking directly the causes of madness and halting the action of evil, destroying it by the root" (CSDNP, diário no 74, de 21 de agosto de 1908; Assembleia da República, 2019b, p. 25-26) and referred to the importance of the creation of an international institute with the purpose of studying and addressing the causes of mental diseases" (CSDNP, diário nº 74, de 21 de agosto de 1908; Assembleia da República, 2019b, p. 25-26).

Contrary to the Law of 1889 , all adjacent hospitals were financed by public works, and not by the fund for the alienated. It also stated that "it is not enough to have hospitals and asylums. They need to have good conditions" (CSDNP, diário $\mathrm{n}^{\circ} 74$, de 21 de agosto de 1908; Assembleia da República, 2019b, p. 25-26). The Senna law was never fulfilled unless for the collection of revenue. The hospital population had increased, and the number of health professionals remained the same. It was, also, not allowed to employ male nurses in the female wards. In 1909, it was concluded that the Hospital of Rilhafoles had no profits with the fund for the alienated. The hospital even had wards where beds had to be made on the ground. Because of the deficient nursing of the hospital, there was a great number of escapes. There was criticism about the lack of hospitals specialized in different services and the belief that nurses should have specialized training in the treatment of alienated patients. There was a debate on who paid or not their hospital expenses and was always evident that the more the paying patients admitted, the fewer places were available to the poor. The conclusion was that the service of the alienated needed a major reform, as well as healthcare delivery to other patients, and once more, the beneficence budget was minute.

\section{Conclusion}

This research allows knowing what the elites discussed about nurses and nursing in this period, in these Houses, to contribute to the objective construction of the history of nursing in Portugal.

The number of references to military nursing is significant, with special emphasis when establishing an analogy with civil nursing. The strong topic is pensions and salaries, but there is relevant information about the Naval Nurses Practice School and the conditions for the apprenticeship of nurses in the Colonial Hospital, military nursing at the time, with structuring levels higher than those of civil nursing. The aspects of the colonial health services became more relevant in the creation of the Colonial Hospital, but also in noting the precariousness in overseas sanitation coverage, with old ships serving as wards.

The religious, healthcare, or confessional quarrel in health institutions spread to overseas. The Peers of the Realm discussed the matter of religion in health, regarding the controversy raised by the action of Father Reyman, and with the lay-brothers of S. Filipe de Nery, based in the Civil Hospitals of Lisbon. The Portuguese assemblymen addressed the question of religion around the homage to Joaquim António de Aguiar. In this respect, the Miguel Bombarda speech about the evil actions of religious congregations was significant. It was possible to identify the position of experts and politicians regarding the identification of diseases and their prophylactic measures, treatments, and how to face the diseases by the ruling power. The two Houses were concerned about the control of epidemics in Coimbra (smallpox) and Porto (bubonic plague). The development of health policies was fundamental and resulted in the creation of new concepts of hygiene and public health, with new health policies. These new practices of hygiene and public health, not always peaceful, sometimes led to revolts against the biopower. One of the facets was 
the reluctance of the populations toward vaccination. There were references to the advantageous specialization of nurses in the area of the alienated, the impediment of male nurses to work with female patients, and the escapes from establishments due to lack of nurses. The fact that the established by the legislation of António Senna was not being complied with was highly criticized, regarding the use of the charitable fund for the construction of wards adjacent to the prisons and hospitals. The care delivery to the alienated was regarded as a sign of civilization and their abandonment as a social downgrade.

\section{References}

Bonifácio, M. F. (2010). A monarquia constitucional $1807-$ 1910 (3a ed.). Alfragide, Portugal: Texto.

Assembleia da República. (2019a). Diários da câmara dos pares do reino (1900-1910). Retrieved from http:// debates.parlamento.pt/catalogo/mc

Assembleia da República. (2019b). Diários da câmara dos Senhores Deputados da Nação Portuguesa (19001910). Retrieved from http://debates.parlamento. $\mathrm{pt} /$ catalogo/mc

Ferreira, J. (2012). A missão e a acção dos enfermeiros militares portugueses: Da guerra da restauração à grande guerra (Ph.D. Thesis). Universidade Católica Portuguesa, Lisboa, Portugal. Retrieved from https://repositorio. ucp.pt/bitstream/10400.14/12371/1/Tese.pdf

Filho, A., Fortes, F., Queirós, P., Peres, M., Vidinha, T., \& Rodrigues, M. (2015). Trajetória histórica da reforma psiquiátrica em Portugal e no Brasil. Revista de Enfermagem Referência, 4(4), 117-125. doi:10.12707/RIV14074

Mattoso, J. (1997). A escrita da história: Teoria e métodos.
Lisboa, Portugal: Editorial Estampa.

Mendes, J. A. (1989). A história como ciência: Fontes, metodologia e teorização (2a ed.). Coimbra, Portugal: Coimbra Editora.

Queirós, P., Filho, A., Almeida, M., Santos, T., Pereira, M., \& Pereira, P. (2018). O cuidado e bom serviço dos enfermeiros em 1821-1822. Revista de Enfermagem Referência, 4(16), 95-106. doi:10.12707/RIV17064

Queirós, P., Filho, A., Monteiro, A., Santos, T., \& Peres, M. (2017). Debates parlamentares em Portugal de 1821 a 1910: Identificação de fontes para a história da enfermagem. Revista da Escola de Enfermagem Anna Nery, 21(1), 1-6. doi:10.5935/1414-8145.20170006

Rosas, F. (2010). Lisboa revolucionária, 1908-1975. Lisboa, Portugal: Tinta da China.

Rosas, F., \& Rollo, M. (2009). História da primeira República Portuguesa. Lisboa, Portugal: Tinta da China.

Rüsen, J. (2001). Razão histórica. Brasília, Brasil: Universidade de Brasília.

Santos, L. (2012). Uma história da enfermagem em Portugal (1143-1973): A constância do essencial num mundo em evolução permanente (Ph.D. Thesis). Universidade Católica Portuguesa, Lisboa, Portugal. Retrieved from https://repositorio.ucp.pt/bitstream/10400.14/12265/1/TD\%20-\%20Dezembro\%202012\%20-\%20Final.pdf

Sardica, J. (2001). Portugal nos primórdios do séc. XX e os últimos anos da monarquia portuguesa. In $\mathrm{R}$. Carneiro \& A. Matos (Eds.), Memória de Portugal, o milénio português (488-489). Lisboa, Portugal: Círculo de Leitores.

Silva, A. (2008). A arte de enfermeiro: Escola de enfermagem Dr. Angelo da Fonseca. Coimbra, Portugal: Imprensa da Universidade de Coimbra.

Torgal, L. R. (2015). Historia, que história?: Notas criticas de um historiador. Lisboa, Portugal: Temas e Debates/ Círculo de Leitores. 